\title{
THE IMPACT OF TASK-BASED LANGUAGE TEACHING ON LEARNERS' WRITING SKILLS
}

\author{
Luz Elena Madera González \\ Department of Foreign Languages, University of Caldas, Manizales, Colombia \\ E-mail: lemadeg@yahoo.es \\ Margarita María López Pinzón \\ Department of Foreign Languages, University of Caldas Calle, Manizales, Colombia \\ E-mail: margarita.lopez@ucaldas.edu.co
}

\begin{abstract}
APA Citation: González, L. E. M., \& Pinzón, M. M. L. (2019). The impact of task-based language teaching on students' writing skills. Indonesian EFL Journal, 5(2), 41-48. doi: 10.25134/ieflj.v5i2.1820.
\end{abstract}

Received: 21-03-2019

Accepted: 25-05-2019

Published: 01-07-2019

\begin{abstract}
This article gives an account of an action research project aimed at determining the effect of TaskBased Language Teaching and various writing strategies on public school learners' writing skills. The study implicated a diagnostic stage, an action stage and an evaluation stage within an Action Research methodology. Initially, at the diagnostic stage, it was detected that the participants had to improve their writing production and reach the levels of competence established by the Common European Framework (CEFR) and The Ministry of National Education (MEN) guidelines. In the following developed phase, six workshops were designed within the framework for Task-Based Learning (Willis \& Willis, 2007), including pre-task, task, planning, report, and language focus. Along with this, various writing strategies were used, including brainstorming, listing, questioning, reading pictures, and classifying words. Finally, the evaluation stage revealed that students achieved better results in written production; they increased their vocabulary, reduced the amount of grammar errors, improved the syntax of the language, and became more autonomous and responsible. Basides, students' confidence in the writing processes also improved. Findings reported that the use of TBLT improved the students' writing skills. Conclusions and pedagogical implications are presented for teachers, schools and policy makers to incorporate TBLT and writing strategies in the future curriculum development as a means to contribute to the English language methodology.
\end{abstract}

Keywords: task-based language teaching; writing process; writing skills; writing strategies.

\section{INTRODUCTION}

The need to support students in their process of learning English and to make teachers feel interested in developing pedagogical language instructions, which provide better opportunities for language learning, had become increasingly significant since English is a worldwide language that allows students to communicate with other people from different countries. Nevertheless, the language learning competence and performance are still focused on the traditional methodology. In Colombia, English has become mandatory. Moreover, its teaching and learning processes are among the main concerns in public and private education institutions so that learners can develop communicative skills needed to compete in an ever-changing market and an increasingly demanding society.

Experts have reached an agreement regarding the need to implement methodologies, strategies and techniques that match current interests, tendencies and technological advances. Trends, such as cross-curricular content, E-Learning and the use of the Information and Communication Technologies (ICT) that connect learners with the outside world are currently highly valued in English classrooms around the world. For these reasons, in order to encourage the attainment of goals proposed for different English courses in formal and informal education for the elaboration of language syllabuses, curriculum guidelines, and examinations, Colombia adopted the standards of the Common European 
Framework of References for Languages (CEFR), with regard to prioritize the quality of the teaching and learning processes and, hence, to obtain better competitiveness, intercultural development, and more academic and job perspectives for the students.

The Ministry of National Education (MEN) in its ten-year plan (2015-2025) has developed educational policies based on international Standards. "El Proyecto de Fortalecimiento al desarrollo de Competencias en Lengua Extranjera" and the Program "Colombia Bilingüe" have been designed and implemented as sustainable initiatives to get better levels of English proficiency in the country. The plan implies the learning of English from elementary to high-school education. Besides, in 2016, MEN created and launched the Suggested English Curriculum and the Basic Learning Rights which allow English teachers and learners to understand the reality of the world and help them to develop communicative competence. These documents consist of pedagogical instructions for educators to follow a curriculum, to evaluate, and to implement some methodological processes which will eventually lead the learning process according to the national standards. In Cartagena (Bolívar), The Secretary of Education, in compliance with the national laws, takes part in these public policies which aim at improving learners' linguistic abilities through its Cartagena Bilingual Program as well.

EFL learning is a concern for the national government and all educational community, i.e., administrators, teachers, students, researchers, and others. This research took place at the public school in Cartagena Bolivar. There are about 879 students and 28 teachers in it. The learners come from the socioeconomic strata one and two and they live in the urban area of Cartagena. They have different types of family structures, such as single parent, blended or extended families whose income mainly comes from informal economic activities and some government subsides. The social context around the school is characterized by a social conflict which has negative impact on the learners' quality of life. The participants of this research were chosen according to Cozby and Bates (2012) convenience sampling, which considers availability, schedule, members, and characteristics. This study was conducted with a group of 36 seventh graders ( 12 boys and 24 girls). Their ages ranged between 12 and 16 . During the diagnostic stage, several data collection instruments were administered to know the attitude of administrators, teachers and students in relation to English teaching and learning process. After analyzing the results, it became evident that low performance in writing, vocabulary, and grammar constituted the main problem. Consequently, writing proved to be a difficult skill for students to master.

Therefore, the researchers decided to implement various writing strategies and techniques to help learners improve their writing skills. Task Based Language Teaching (TBLT) was chosen to promote the development of this skill. This highlighted the need for teachers to create opportunities for successful language learning experiences and implement meaningful tasks that would support learning process. As a result, the study intended to intervene this EFL context in order to promote learners' writing skills. After analyzing the learning needs, the research question proposed in this study was: "to what extent can task-based language teaching influenced seventh grader's writing skills development a public school in Cartagena?" Relevance of writing in English

There are many reasons for asking students to write. As Smith stated, "we write for at least two reasons. First, and most obvious, we write to communicate with others. But, perhaps more important, we write for ourselves, to clarify and stimulate our thinking" (cited in Manyike \& Lemmer, 2010, p. 43). Another reason is that writing helps students to learn and facilitates understanding information and expressing ideas. Furthermore, the authors believed that writing exercises provide students with opportunities to explore new ideas, organize them, think critically and 
Indonesian EFL Journal (IEFLJ)

Volume 5, Issue 2, July 2019

improve their ability to communicate. When teachers catch the students' interests and recognize their needs, they can engage the students with different tasks in class since writing exercises make students aware of the thinking process involved.

\section{The writing process stages}

The writing process considers a series of steps for students to develop this skill. This study based the design of the intervention activities on the model proposed by Harmer (2011a) which portrays the writing as a process which involves four main elements, namely planning, drafting, editing (reflecting and revising), and final version.

\section{What to consider when teaching writing}

Teaching and learning to write is not an easy task because there are many aspects which must considered, such as grammar, vocabulary, and mechanics of writing in order to produce a clear piece of writing. First, students need to learn time-management skills which tends to take some time and training. Second, students must think and organize their ideas to express a message. This process of organizing their writing must follow some steps. According to Sokolik in Nunan (2003, pp .87-88), "writing is a combination of process and product". The process refers to the act of gathering ideas or the steps a writer takes when he produces a piece of writing, whereas the product is known as a final piece of writing. In other words, when producing any type of texts, the writer must follow some steps until he produces his final paper. Third, it is essential to think of some other issues related to writing when teachers ask students to write. According to Harmer (2011b), the kind of writing the teacher asks students to do and the way the teacher asks them to do have some relevances in the product the teacher receives from them. Moreover, the kind of writing and the style will depend on their age, level, learning styles, and interest. Students should start from simple and move on to complex texts. Teachers should ask students to start with simple narrative compositions in order to help them build their confidence because confident learners work and learn
p-ISSN 2252-7427, e-ISSN 2541-3635

https://journal.uniku.ac.id/index.php/IEFLJ/index

more as well as know how to get their point across.

\section{Task-based language teaching approach}

As Ellis (2003) believes, TBLT is an approach

to language teaching that provides opportunities for students to engage in the authentic use of the target language through tasks. As the principal component in TBLT, the task provides the main context and focus for learning and it encourages language use like the way language is used outside the classroom. Students learn language and develop skills as they work toward completing the task which motivates them to stretch their available language resources (Ellis, 2003). Another definition associated with TBLT was formulated by Richards and Rogers (2001). They affirmed that "Task-Based Language Teaching (TBLT) refers to an approach based on the use of tasks as the core unit of planning and instruction in language teaching" (Richards \& Rogers, 2001, p. 223). The use of TBLT in the classroom proposed by these authors is summarized as follows: 1) Activities that involve real communication are essential for language learning, 2) Activities in which language is used for carrying out meaningful tasks that promote learning, and 3) Language that is meaningful to the learner supports the learning process.

\section{Studies about writing}

The studies described in this subsection were significant for the research project as they provide some insights on how to apply the knowledge in the field of teaching writing and useful information regarding the teaching and learning process of writing skill.

One of these studies is a research conducted by by Barkaoui (2007) entitled "Teaching writing to second language learners: Insights from theory and research." In his paper, the author summarizes the main findings of L2 writing theory and research related to the nature of the writing competencies that learners need to develop to be able to write effectively. He also describes how instructor can help them attain these competencies. Barkaouki intends to answer the following question: "What do students need to learn to become effective L2 writers?" 


\section{Luz Elena Madera González \& Margarita María López Pinzón}

The impact of task-based language teaching on students' writing skills

First, he states that they need to learn the orthography, morphology, lexicon, syntax as well as the discourse and rhetorical conventions of L2. Secondly, he mentions that process-oriented research sees learning L2 writing as the acquisition of successful writing strategies. From this perspective, learning L2 is seen as the acquisition of both macro strategies, such as planning, drafting and revising as well as micro strategies, such as attending to content and form concurrently and automatic search for words and syntax (Cummings, 2001). Furthermore, Barkaoui (2007) also mentions several aspects that are related to affective, linguistic, cognitive and socio-cultural factors. His study provides instructor on what aspect of writing to teach and how to teach it to L2 learners. Additionally, he suggests some teaching practices and makes some recommendations for teachers to improve their practice. He considers that teachers need to raise learners' awareness about successful writing processes, L2 reader expectations, and L2 linguistic and textual conventions. In addition, Barkaoui states that learners should be provided with models, clear and specific learning goals, meaningful context to practice writing, carefully structured activities, clear presentations of materials, useful feedback, encouragement, and high standards. $\mathrm{He}$ concludes the paper pointing out that teachers need to promote learner autonomy in and outside the L2 writing classroom.

Another study was conducted by Mohite (2014) in a secondary school in London with Polish EFL learners. The researcher explored students' opinions and beliefs regarding their English language writing strategies and intended to relate these variables to the students' writing performance. This study provided valuable insights into components of writing process and students' opinions about effective writing strategies. Mohite applied mixed-method approach - that is to say, quantitative and qualitative analysis. The objective of the quantitative approach was to generate hypotheses using grounded theory. She hoped that the qualitative data provided her with an in-depth insight into the nature of
L2 writing and thus would enable the formulation of new hypotheses. She confirmed with the quantitative analysis that good language learners used various writing strategies, but the finding was not significant. The qualitative analysis rendered two new hypotheses which seemed to provide an explanation why students in the studied sample struggled with their English writing. They lacked the understanding of the compositional aspect of the English writing and they did not view their English writing as a means of communication. Therefore, the implications of the research were; to raise the students' awareness of the English writing compositional skills, to emphasize the communicative purpose of writing in English, and to train them to use peer collaboration strategy to facilitate their English writing most effectively.

\section{METHOD}

This study was carried out based on the Action Research methodology which is defined by McNiff and Whitehead (2005, p.1) as "a common-sense approach to personal and professional development that enables practitioners everywhere to investigate and evaluate their work, and to create their own theories of practices."

According to the preliminary research, important decisions were made on the EFL teaching and learning processes. Some changes are going to be implemented in the areas which needed improvement in the classroom based on participants', teachers', and administrators' opinions. Right after that, the problem was identified by considering various facts and perceptions of the issue. Accordingly, this study involved a process that required planning, observing, acting, and reflecting on the data from a big number of seventh graders.

Thirty-six seventh-graders consisting of twenty-four girls and twelve boys participated in this study. Their ages ranged between 12 and 16. The instruments used in this study were students' questionnaire, students' pretest, teacher's questionnaire, administrator's 
questionnaire, teacher's journal, and students' post-test.

The first phase was a preliminary diagnosis which involved the application of four instruments providing a broad picture of the setting, the teaching practices, the participants and their concerns and difficulties related to English teaching and learning process. During the action stage, six workshops were designed under the Task-Based Language Teaching approach in which learners' engagement in meaningful tasks was the primary focus. Students' setting, needs and motivation were all considered in the workshops, and the tasks designed were of growing interest for the participants. Although the activities integrated the four skills of the language, following the TBLT approach, the students' writing process was based on the phases of planning, drafting, editing, and final version.

The workshops were developed considering the Willis and Willis' (2007) teaching cycle which consists of pre-task, main task, planning, report, and language focus. They encouraged the participants to use the vocabulary learned during the pre-task activities. Moreover, the objectives of each workshop was aligned with the guidelines of MEN (2006) concerning the requirements for foreign language proficiency standards. The activities involved a wide range of tasks, such as writing a paragraph, describing family, writing poems, describing a problem, and giving tips or advice. After the implementation of each workshop, students' progress was evaluated by using a rubric and questionnaires.

To analyze the collected data, the researchers firstly analyzed the students' questionnaire and administrator's responses. Then, the researchers examined the teacher's questionnaire and Journal entries to code the data for preliminary categories. Next, in the action and evaluation stage, the data were analyzed following the same procedure, such as coding and grouping in order to determine if there were convergence.

\section{RESULTS AND DISCUSSIONS}

The general pedagogical objective of this study was to enhance students' writing skills through the implementation of Task-Based Language Teaching. Meanwhile, the specific pedagogical objectives were; 1) to increase students' writing production in L2 with coherence and accuracy, 2) to promote the development of students' writing skills by using different strategies, and 3) to raise learners' confidence towards the writing process to express their very particular communicative needs. As results, the analysis revealed that the students made significant advances in terms of vocabulary, syntax, grammar, and in their writing skill as a whole. The results of the analysis are described below.

\section{TBLT increased students' self-confidence in written production}

The students felt confident during the implementation of the workshops since the lessons were planned according to their interests and needs. Moreover, they confirmed that they had gained knowledge and needed to learn English to have better academic performance and job opportunities. besides, they had the opportunity to interact with their classmates to complete their task working in groups. Therefore, they were able to share time with their classmates and enjoyed completing tasks together. They were engaged in tasks and they tried doing their best in each. task. The students worked enthusiastically and exchanged information related to each task presented in the workshops. In addition, the analysis of data collection instruments showed that the students achieved the learning goal proposed in each workshop and there was a performance gradual progress.

\section{Students' improvement in the writing process}

Writing was one of the biggest challenges for the students since they found it difficult. However, as the time went by, they became confident in the writing process since they could plan, draft and edit their writing pieces. Furthermore, they had time to reflect and revise until the text was ready to be collected and rated. Accordingly, the students were able 
to write sentences clearly and logically organized.

Students' improvement in their writing, vocabulary, spelling, revising and thinking skills

The tasks presented in the workshops helped the students to deal with some grammatical aspects since students used to make mistakes in their written work at the very beginning of this study. The stages of writing encouraged them to organize their ideas and taught them to think, plan, and revise their drafts. They improved their knowledge of English grammar and the use of some connectors and expressions related to the contents. Moreover, the students made great lexical advances because they enhanced their vocabulary knowledge and refined their spelling.

Students' improvement in text construction and collaborative writing

As the students completed the tasks throughout the Action Stage, they found it much easier to write and became better writers. It was crucial for them to plan, draft, reflect, revise and spend some time editing their drafts to produce their final version since the stages of the writing process made them aware of their own mistakes and helped to decide what had to be changed. Moreover, the students worked in teams and learned from each other. The fact was that the students had to interact with different classmates while reading their drafts, correcting mistakes and creating a coherent text; that way, they were able to express their ideas to their peers and learn from them.

\section{Motivating and provoking tasks}

The students achieved different goal in each task and it was noticeable the use of creativity since they illustrated and designed a neat piece of writing. The students found the activities very interesting and their motivation made them work with excitement. Students' performance increased significantly. In brief, TBLT helped them achieve the goals proposed in the tasks.

Portfolios for following progress and assessing writing

Portfolios resulted to be a useful tool for the students to self-evaluate their written production and identify their weaknesses and strengths. Moreover, it was important for them to keep a portfolio in order to organize and collect their writing experiences. When the students finished a task or completed all their writing assignments, they continuously reflected on their growth, encouraged creativity, and experimented different levels of improvement. Moreover, when the students were observing their written productions, they were able to see their progress which affected their confidence in a positive and motivating way. The portfolio also allowed the students to monitor their own progress. Moreover, the rubrics for grading their production included important criteria for assessing the writing competence. Regarding the learning goals, it measures the growth in the learning process and the progress in the writing ability. The findings also revealed that portfolios encouraged students to think critically as well as to develop their learning autonomy.

All in all, the implementation of task based language teaching to help students improve their writing skill results in the improvement of students' self-confident as well as their spelling, vocabulary, and mechanics of writing. Besides, the use of the language in communicative contexts, being more precise when it came to produce a text or composition.

\section{CONCLUSION}

Writing is one of the language skills which requires hard work and dedication until the skill is acquired. However, there are some additional features in the art of teaching which makes students improve their writing skills. After implementing TBLT, there are some essential key points in the development of the writing tasks. First, the teacher has to involve students in the process of choosing the topic to guarantee that they will participate in the writing tasks with enthusiasm. Second, it is essential to plan and design tasks which allow students to develop and improve the sub-skills needed to produce a written product. Third, it is important to guide students in the stages of writing (planning, drafting, editing reflecting and revising, and final version) until they can do it by themselves. Fourth, the 
teacher needs to provide students with opportunities to monitor their progress focusing on clear criteria of assessment, for instance, a rubric. Otherwise, the students that do not use clear criteria for assessment do not experience effective learning since they do not know what the learning outcomes are and what aspects they need to improve.

The implementation of TBLT approach has a positive impact on students' English proficiency level since it helps students improve their writing skills. Additionally, TBLT promotes activities that are favorable for the learning process. Moreover, group work is an opportunity for students to create spaces to generate ideas and find an attractive way to present the task. However, they do not only make improvements in the organization and edition of the tasks, but also improve their grammar and the way of expressing ideas. It means that they are able to write more coherently and use the vocabulary they learned. This methodology provides students with more opportunities to enhance language learning and develop writing skills due to students' involvement in real-world challenges. Likewise, students are encouraged to gain some confidence and develop autonomy in their learning process. When students work in pairs or teams, they get a better understanding of the lessons since they can learn from their peers. Moreover, they feel the support of their classmates. The students do not only share ideas but also materials. They are more productive and develop communication skills easier since they collaborate and share ideas.

This study determines the effect of writing strategies through TBLT approach on an EFL classroom. It reports valuable experiences in teaching writing. In addition, the pedagogical implications of the present study are significant for students, teachers, institutions, and educational policy makers since TBLT approach is useful for teachers and students to plan, carry out tasks, assess and achieve goals when learning a language. TBLT approach can be used to engage learners in learning, promote real-life communicative situations and students' autonomy since they are the center of the learning process. Moreover, TBLT increases students' written production as compared to the traditional teaching methodology. In addition, the structure of the lessons in TBLT fosters different tasks which facilitates a dynamic role of the students and a communicative interaction among them as they can work in groups or teams.

Basically, there are challenges in the field of teaching writing skills since written communication in English is essential in these days. The changing world forces people to be able to use different languages and their written communication must be effective. In this regard, many studies are carried out in order to investigate and find the most effective and efficient way of developing writing skill. Therefore, the researchers consider this study would contribute to the education system due to the benefits in achieving communicative competence and increasing students' language use. The researchers would also suggest including TBLT as a teaching option which enhances students' writing skills. TBLT approach can help students to develop meaningful communication because tasks can motivate students to learn English and develop their writing skill. However, teachers should not neglect the target of planning and designing tasks lies on learners' particular communicative needs.

Considering that this study was conducted in order to improve students' writing skills, it is worthwhile to mention that the production of a piece of writing presupposes the application of some strategies dealing with grammar, word choice, mechanics, etc., as well as the implementation of TBLT approach. Teaching writing is a very important skill that must not be underestimated. Teachers and the academic community should continue doing emphasis on the writing process which is usually overlooked in the EFL classes.

\section{ACKNOWLEDGEMENTS}

I thank God for listening to my prayers and giving me wisdom and understanding that were necessary to carry out this research. Besides, I would like to give my gratitude to 


\section{Luz Elena Madera González \& Margarita María López Pinzón}

The impact of task-based language teaching on students' writing skills

my thesis advisor, Margarita María López Pinzón, the Director and Professor of the Master's Program in English Didactics at Universidad de Caldas, who constantly motivated me during the development and evolution of this research. I really want to thank her for the invaluable support, kindness, and appropriate response to all my doubts. My thanks also go to my seventh graders at Institución Educativa Playas de Acapulco for their cooperation with the implementation of the project. Moreover, I also want to thank my beautiful daughter Hellen Sophia Macías Madera who sacrificed her time and understood how important it was for her mother to finish the research project. Last but not least, I would like to express my gratitude to Henry Edgardo Macías Montaño for always supporting me.

\section{REFERENCES}

Barkaoui, K. (2007). Teaching writing to second language learners: Insights from theory and research. TESL Reporter, 40, 35-48.

Cozby, P., C. \& Bates, S., C. (2012). Methods in behavioral research. New York: McGraw-Hill Companies.

Cummings, A. (2001). Learning to write in a second language: Two decades of research. International Journal of English Studies, 1-23.
Ellis, R (2003). The methodology of task-based teaching. Retrieved from https://www.kansaiu.ac.jp/fl/publication/pdf_education/04/5rodellis. pdf.

Harmer, J. (2011a). How to teach English. England: Pearson Education Limited.

Harmer, J. (2011b). The practice of English language. England: Pearson Education Limited.

Manyike, T., V. \& Lemmer, E., M (2010). English reading and writing performance of Xitsongaspeaking grade 7 learners in township schools: A case study. University of South Africa.

Ministry of Education. (2006). Estándares Básicos de Competencia. (M. o. Education, Ed.) Retrieved from

http://www.colombiaaprende.edu.co/html/mediat eca/1607/articles-115375_archivo.pdf.

Mohite, M. (2014). An investigation into the English language writing strategies used by Polish EFL secondary school learners. British Council ELT. London Metropolitan University.

McNiff, J., \& Whitehead. J. (2005). Action research for teachers: A practical guide. Madison Avenue: David Fulton Publishers.

Richards, J. C., \& Rodgers, T., S. (2001). Aproaches and methods in language teaching (3rd ed.). Cambridge: Cambridge University Press.

Sokolik, M. (2003). Writing. In D. Nunan (Eds), Practical English language teaching (PELT), (pp. 87-88). New York: McGrawhill.

Willis, D., \& Willis, J. (2007). Doing task-based teaching: Handbooks for language teachers. Oxford: Oxford University Press. 